\title{
Photodynamic Stress-Induced Nonenzymatic Antioxidant Responses in Transgenic Rice Overexpressing 5-Aminolevulinic Acid Synthase
}

\author{
Sunyo Jung ${ }^{1 *}$ \\ 5-Aminolevulinic Acid Synthase를 과발현하는 형질전환 벼에서 \\ 광역학적 스트레스가 유도하는 비효소적 항산화반응
}

정 선 요 $^{1 *}$

\begin{abstract}
We investigated photodynamic stress-induced antioxidant responses in transgenic rice overexpressing Bradyrhizobium japonicum 5-aminolevulinic acid synthase (ALA-S) coding sequence lacking plastidal transit sequence. High light of $350 \mu \mathrm{mol} \mathrm{m} \mathrm{m}^{-2} \mathrm{~s}^{-1}$ decreased the quantum yield in the transgenic lines, $\mathrm{C} 4$ and $\mathrm{C} 5$, compared to that of wild-type line. By contrast, non-photochemical quenching (NPQ) levels of C4 and C5 under high light were higher than those of the transgenic lines under low light of $150 \mu \mathrm{mol} \mathrm{m} \mathrm{m}^{-2} \mathrm{~s}^{-1}$ as well as wild-type line under low and high light. Greater levels of NPQ in the transgenic lines exposed to high light were in a close correlation with increases in the xanthophyll pigment, zeaxanthin. Under high light, levels of neoxanthin, violaxanthin, lutein, and $\beta$-carotene in the transgenic lines were lower than those in wild-type line. Taken together, nonphotochemical energy dissipation and photoprotectant xanthophyll pigments play a critical role to deal with the severe photodynamic damage in the transgenic rice plants, although they could not overcome the photodynamic stress, leading to severe photobleaching symptoms.
\end{abstract}

Key words: 5-aminolevulinic acid; 5-aminolevulinic acid synthase; NPQ; photodynamic stress; xanthophyll.

\section{INTRODUCTION}

The formation of 5 -aminolevulinic acid (ALA) is the first committed step that links to the regulation of other intermediates in the porphyrin pathway (Rebeiz et al. 1984; von Wettstein et al. 1995). In plants, ALA is

\footnotetext{
${ }^{1}$ School of Life Sciences and Biotechnology, Kyungpook National University, Daegu 702-701, Korea(경북대학교 생명공학부, 702-701 대구광역시 북구 산격동 1370).

* 연락저자(Corresponding author) : Phone) +82-53-950-7364, Fax) +82-53-943-6925, E-mail) sjung@ @nu.ac.kr
}

(Received November 2, 2011; Revised November 28, 2011; Accepted December 5, 2011)

(C) 2011 Korean Society of Weed Science 
formed from the $\mathrm{C}_{5}$ skeleton of glutamate by enzymatic reactions of glutamyl-tRNA synthetase, glutamyl-tRNA hydrogenase, and glutamate-1-semialdehyde aminotransferase (Beale 1978). Eight ALA molecules are fused into porphyrins which are then modified to protoporphyrin IX (Proto IX). The chelation of Proto IX with $\mathrm{Mg}^{2+}$ leads to chlorophyll. In Bradyrhizobium japonicum, ALA is synthesized by ALA synthase (ALA-S), which catalyzes the first step in heme synthesis, the condensation of glycine and succinyl-CoA, releasing carbon dioxide and CoA.

A low concentration of ALA application was found to increase the growth and yield of radishes, kidneybeans, barley, potatoes, and garlic by 10 to $60 \%$ (Hotta et al. 1997; Sasaki et al. 1998). The practical application of ALA as a selective, not harmful and biodegradable herbicide was demonstrated by Rebeiz et al. (1984). When plants treated with high concentration of ALA are exposed to light, excess tetrapyrroles absorb energy that is utilized in photochemical reactions and photosensitizes the production of singlet oxygen $\left({ }^{1} \mathrm{O}_{2}\right)$, which oxidizes unsaturated fatty acids on the cell surface, thereby damaging the plant (Hopf and Whitten 1978; Tripathy and Chakraborty 1991; Jung 2009).

To protect the photosynthetic apparatus from photooxidative destruction, plants must dissipate excess light energy. The protection may be afforded by down-regulation of the photochemical efficiency via the action of the xanthophyll cycle pigments (DemmigAdams et al. 1996; Jung and Steffen 1997). Nonradiative energy dissipation at photosystem (PS) II is mediated by zeaxanthin and antheraxanthin (Gilmore and Yamamoto 1991) and is proposed to occur at several sites within or around the PSII reaction center (Weis and Berry 1987). Researchers have used differential terms for energy dissipation, e.g. the quenching coefficient qN (Schreiber et al. 1994) versus Stern-Volmer quenching (Bilger and Björkman 1990; Gilmore and Yamamoto 1993) that is referred to as non-photochemical quenching (NPQ).

Rice plants overexpressing B. japonicum ALA-S coding sequence lacking plastidal transit sequence increased levels of ALA and photoreactive porphyrin intermediates, thereby resulting in photobleaching of plants under high light (Back and Jung 2010). In this study, we investigated the effect of ALA-S overexpression on energy dissipation mechanism of wild-type and transgenic rice plants under photodynamic stress conditions. The non-enzymatic antioxidant mechanism of photoprotective pigments is also compared between wild-type and transgenic rice plants.

\section{MATERIALS AND METHODS}

\section{Plant materials and growth conditions}

Scutellum-derived calli of rice (Oryza sativa cv. Dongjin) were co-cultured with Agrobacterium tumefaciens LBA4404 harboring the binary vector pGA1611 : ALA-S (without plastidal transit sequence; $C$ line) (Back and Jung 2010). The B. japonicum ALA-S coding sequence lacking the plastidal transit sequence was introduced into rice plants. The $\mathrm{T}_{4}$ generation of homozygous transgenic rice lines, $\mathrm{C} 4$ and $\mathrm{C} 5$, was used for experiments. Uncoated seeds of untransformed and transgenic lines were sterilized in 3\% Chlorox, washed with sterilized water, put for 3 days at $25^{\circ} \mathrm{C}$ in darkness on MS solid medium, and then exposed to either photosynthetic photon flux density (PPFD) of either $150 \mu \mathrm{mol} \mathrm{m} \mathrm{m}^{-2} \mathrm{~s}^{-1}$ (low light) or $350 \mu \mathrm{mol} \mathrm{m} \mathrm{m}^{-2}$

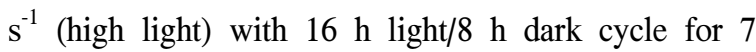
days. The high light level of $350 \mu \mathrm{mol} \mathrm{m} \mathrm{m}^{-2}$ was used for inducing photoinhibitory stress in plants. Leaf tissues were taken for all experiments.

\section{Pigment extraction and analysis}

For carotenoid analysis, leaf tissues $(0.1 \mathrm{~g})$ were ground in $1 \mathrm{~mL}$ of $100 \%$ acetone containing $10 \mathrm{mg}$ $\mathrm{CaCO}_{3}$. The extracts were centrifuged at $16,000 \times \mathrm{g}$ for $10 \mathrm{~min}$ and the resulting supernatants were collected. The pigments were separated by HPLC using a Waters 2690 System (Millipore, Milford, MA, USA) equipped

(C) 2011 Korean Society of Weed Science 
with a Waters 2487 Absorbance Detector (Millipore, Milford, MA, USA) and a Spherisorb ODS- 1 column (5- $\mu \mathrm{m}$ particle size, $250 \times 4.6 \mathrm{~mm}$ id) (Alltech Inc., Deerfield, IL, USA). Solvent A (acetonitrile : methano $1: 0.1 \mathrm{M}$ Tris- $\mathrm{HCl}(\mathrm{pH} 8.0), 72: 8: 3$ ) was run isocratically from $0-4$ min followed by a 2.5 min linear gradient to $100 \%$ solvent B (methanol : hexane, $4: 1$ ) at a flow rate of $2 \mathrm{~mL} \mathrm{~min}^{-1}$ (Gilmore and Yamamoto 1991). The detector was set at $440 \mathrm{~nm}$ for the integration of the peak areas. Chlorophyll concentration was measured spectrophotometrically by the method of Lichtenthaler (1987).

\section{Measurement of chlorophyll a fluorescence}

Chlorophyll a fluorescence was measured in vivo using a pulse amplitude modulation fluorometer (PAM2000, Walz, Effeltrich, Germany) after dark adaptation for $10 \mathrm{~min}$. Minimal chlorophyll fluorescence yield, $\mathrm{F}_{\mathrm{o}}$, was obtained upon excitation with a weak measuring beam from a pulse light-emitting diode. Maximal chlorophyll fluorescence yield, $\mathrm{F}_{\mathrm{m}}$, was determined after exposure to a saturating pulse of white light to close all reaction centers. The quantum yield of electron transport through PSII (ФPSII $=\Delta \mathrm{F} / \mathrm{F}_{\mathrm{m}^{\prime}}: \Delta \mathrm{F}=$ $\mathrm{F}_{\mathrm{m}}-\mathrm{F}_{\mathrm{t}} ; \mathrm{F}_{\mathrm{m}}$, maximal chlorophyll fluorescence in light adapted state; $\mathrm{F}_{\mathrm{t}}$, chlorophyll fluorescence in steady state), which measures the quantum efficiency of PSII, was calculated as defined by Genty et al. (1989). It provides a quick and useful estimate of light reaction activity and photosynthetic rate. NPQ was quantified, as previously done by Bilger and Björkman (1990) according to the Stern-Volmer equation, $N P Q=F_{m} / F_{m}$ -1 .

\section{RESULTS and DISCUSSION}

\section{Effect of ALA-S overexpression on energy dissipation mechanism induced by photodynamic stress}

In our previous study, the photobleaching symptom of transgenic rice plants overexpressing B. japonicum ALA-S coding sequence lacking plastidal transit sequence (C4 and C5 lines) under high light appeared to result from a greater level of Proto IX due to the ectopic accumulation of ALA (Back and Jung 2010). In ALA-treated plants exposed to light, the excess Proto IX accumulation generates ${ }^{1} \mathrm{O}_{2}$, which oxidizes unsaturated fatty acids on the cell surface and leads to cell death (Rebeiz et al. 1984). In the present study, we investigated photodynamic stress-induced antioxidant responses in transgenic rice overexpressing ALA-S. Total chlorophyll contents significantly decreased under high light of $350 \mu \mathrm{mol} \mathrm{m} \mathrm{m}^{-2} \mathrm{~s}^{-1}$ compared to low light of $150 \mu \mathrm{mol} \mathrm{m}^{-2} \mathrm{~s}^{-1}$ in the transgenic lines $\mathrm{C} 4$ and $\mathrm{C} 5$, indicating the extent of photobleaching in the transgenic plants (Fig. 1). However, wild-type line did not show a great change in chlorophyll content. The transgenic lines, C4 and C5, developed the greater levels of photoprotective responses in comparison to wild-type line. We examined the energy dissipation mechanism of

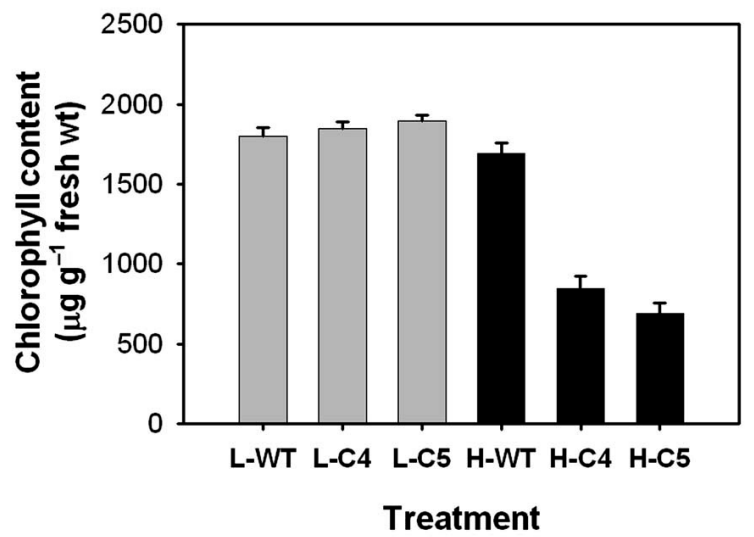

Fig. 1. Effect of photodynamic stress induced by ALA-S overexpression on total chlorophyll content. Uncoated and sterilized seeds of the wild-type line and transgenic lines $\mathrm{C} 4$ and $\mathrm{C} 5$ were grown on MS solid medium in darkness at $25^{\circ} \mathrm{C}$ for 3 days and then exposed to either a PPFD of $150 \mu \mathrm{mol} \mathrm{m} \mathrm{m}^{-2} \mathrm{~s}^{-1}$ (low light) or $350 \mu \mathrm{mol} \mathrm{m} \mathrm{m}^{-2} \mathrm{~s}^{-1}$ (high light) for 7 days. L, low light; H, high light; WT, wild type; $\mathrm{C} 4$ and C5, $\mathrm{T}_{4}$ generation of homozygous transgenic rice lines expressing the B. japonicum ALA-S coding sequence lacking the plastidal transit sequence. Data represent the mean \pm SE of three replicates.

(C) 2011 Korean Society of Weed Science 
A

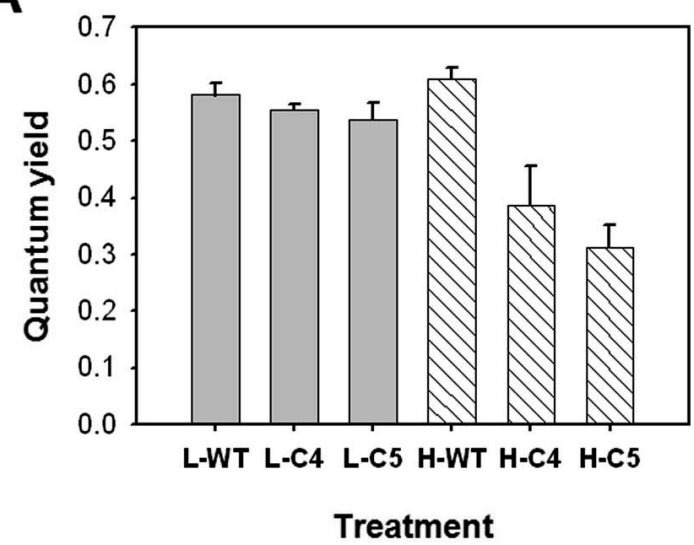

B

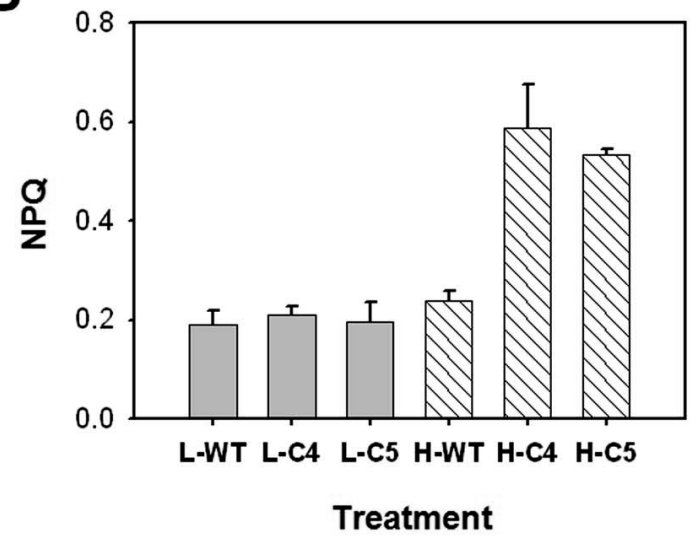

Fig. 2. Effect of photodynamic stress induced by ALA-S overexpression on quantum yield and nonphotochemical quenching. Quantum yield of electron transport through PSII (A); Stern-Volmer quenching, referred to as nonphotochemical quenching (B). Uncoated and sterilized seeds of the wild-type line and transgenic lines $\mathrm{C} 4$ and $\mathrm{C} 5$ were grown on MS solid medium in darkness at $25^{\circ} \mathrm{C}$ for 3 days and then exposed to either a PPFD of $150 \mu \mathrm{mol} \mathrm{m}^{-2} \mathrm{~s}^{-1}$ (low light) or $350 \mu \mathrm{mol} \mathrm{m} \mathrm{m}^{-2} \mathrm{~s}^{-1}$ (high light) for 7 days. L, low light; $\mathrm{H}$, high light; WT, wild type; $\mathrm{C} 4$ and $\mathrm{C} 5, \mathrm{~T}_{4}$ generation of homozygous transgenic rice lines expressing the $B$. japonicum ALA-S coding sequence lacking the plastidal transit sequence. Data represent the mean $\pm \mathrm{SE}$ of three replicates.

ALA-S-expressing transgenic rice upon different light intensities. In low light of $150 \mu \mathrm{mol} \mathrm{m} \mathrm{m}^{-2} \mathrm{~s}^{-1}$, quantum yield of electron transport through PSII and NPQ were similar between wild-type and transgenic lines, $\mathrm{C} 4$ and C5 (Fig. 2A). Overall, quantum yield of PSII under high light of $350 \mu \mathrm{mol} \mathrm{m} \mathrm{m}^{-2} \mathrm{~s}^{-1}$ was substantially lower in the transgenic lines compared to the transgenic lines under low light as well as the wild-type line under low and high light. By contrast, under high light conditions, Stern-Volmer quenching, NPQ, slightly increased in wild-type line, compared to that of low light conditions (Fig. 2B). Interestingly, the transgenic lines, $\mathrm{C} 4$ and $\mathrm{C} 5$, exposed to high light exhibited a greater increase in NPQ than those in wild-type line (Fig. 2B). This result indicates an efficient dissipation of excess light energy in the transgenic lines. Damaged PSII reaction centers are known to as sites of thermal dissipation and a scavenger of active oxygen species (Krause 1988, Sharma et al. 1997; Trebst 2003). However, the increased level of energy dissipation through NPQ could not overcome the photodynamic stress in the ALA-S-expressing transgenic lines, leading to severe photobleaching symptoms.

\section{Photodynamic stress-induced alterations in levels of photoprotectant xanthophyll pigments}

Protection of cells against ${ }^{1} \mathrm{O}_{2}$ is generally believed to be mediated by carotenoids which are membranebound antioxidants that can quench ${ }^{3}$ chlorophyll and ${ }^{1} \mathrm{O}_{2}$, inhibit lipid peroxidation, and stabilize membranes (Demmig-Adams et al. 1996, Mittler et al. 2004). Under high light of $350 \mu \mathrm{mol} \mathrm{m} \mathrm{m}^{-2}$, violaxanthin levels increased greatly only in wild-type line, compared to those of low light of $150 \mu \mathrm{mol} \mathrm{m}^{-2} \mathrm{~s}^{-1}$ (Fig. 3B). Levels of neoxanthin, lutein, and $\beta$-carotene did not change significantly in the wild-type line exposed to high light, but decreased in the $\mathrm{C} 4$ and $\mathrm{C} 5$ lines (Fig. 3A, D and F). This result may be due to impairment in the assembly of chlorophylls and the pigment-binding proteins and a deficiency for the increased need for redox equivalents in the photobleached transgenic plants. By contrast, levels of the possible photoprotectant, antheraxanthin, were significantly accumulated in both wild-type and transgenic lines when exposed to high light in comparison to those of low light (Fig. 3C). In response to high light of $350 \mu \mathrm{mol} \mathrm{m}^{-2} \mathrm{~s}^{-1}$, the level of 
A

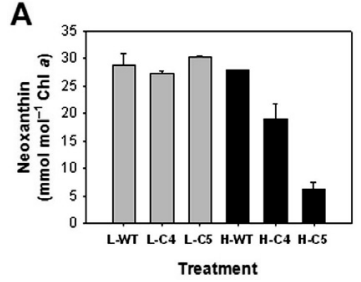

C

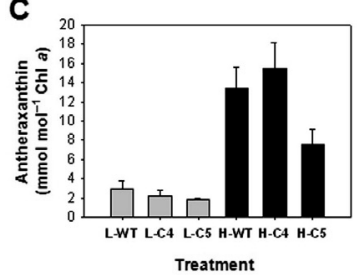

E

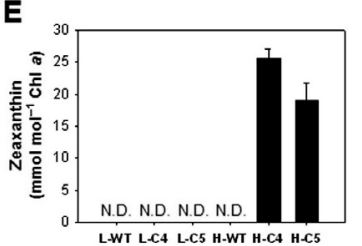

Treatment
B

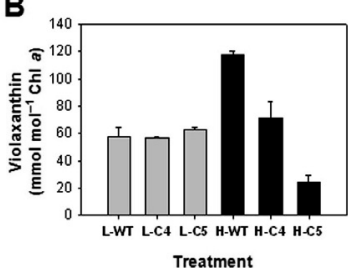

D

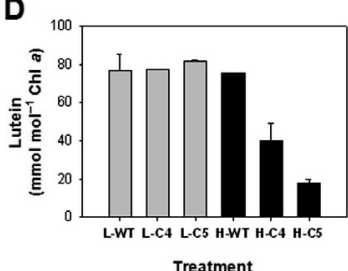

F

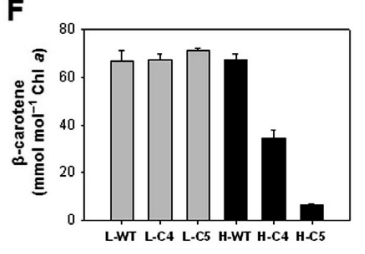

Fig. 3. Effect of photodynamic stress induced by ALA-S overexpression on carotenoid contents. Neoxanthin (A); Violaxanthin (B); Antheraxanthin (C); Lutein (D); Zeaxanthin (E); $\beta$-carotene (F). Uncoated and sterilized seeds of the wild-type line and transgenic lines C4 and C5 were grown on MS solid medium in darkness at $25^{\circ} \mathrm{C}$ for 3 days and then exposed to either a PPFD of $150 \mu \mathrm{mol} \mathrm{m} \mathrm{m}^{-2} \mathrm{~s}^{-1}$ (low light) or 350 $\mu \mathrm{mol} \mathrm{m} \mathrm{m}^{-2} \mathrm{~s}^{-1}$ (high light) for 7 days. L, low light; $\mathrm{H}$, high light; WT, wild type; $\mathrm{C} 4$ and $\mathrm{C} 5, \mathrm{~T}_{4}$ generation of homozygous transgenic rice lines expressing the B. japonicum ALA-S coding sequence lacking the plastidal transit sequence; N.D., not detected. Data represent the mean $\pm \mathrm{SE}$ of three replicates.

zeaxanthin appeared to be newly formed at the expense of violaxanthin via the xanthophyll cycle interconversion (Fig. 3E).

NPQ is proportional to the effective rate constant for energy dissipation in the antennae as well as to the concentration of quenching centers (Demmig-Adams et al. 1996). Higher levels of NPQ in the transgenic lines exposed to high light were in a close correlation with an increase in the xanthophyll zeaxanthin (Figs. 2 and 3). Binding of zeaxanthin and protons to the lightharvesting complex is known to cause a conformational change that is necessary for thermal dissipation (Bilger

and Björkman 1990; Ruban et al. 1993). Quenching of ${ }^{1}$ chlorophyll, ${ }^{1} \mathrm{O}_{2}$, and possibly also inhibition of lipid peroxidation are impaired in the absence of both zeaxanthin and lutein (Niyogi et al. 1997). Active oxygen species produced in plants are normally detoxified by both enzymatic and non-enzymatic antioxidants present in all compartments, especially at sites where oxygen radicals are usually photogenerated (Foyer et al. 1994). Enzymatic antioxidants including superoxide dismutase, catalase, and peroxidase may also play a critical role in detoxification of photodynamic stresses imposed by high light condition.

Taken together, nonphotochemical energy dissipation and photoprotectant zeaxanthin play a critical role to deal with the inevitable generation of photodynamic damage in the transgenic rice plants expressing ALA-S lacking plastidal transit sequence. However, a perturbed balance between generation and scavenging of photodynamic stress cannot overcome photodynamic damage imposed by excessive accumulation of porphyrin intermediates under high light conditions. In the present study, we elucidated photodynamic stress-induced antioxidant responses in transgenic rice overexpressing ALA-S, providing the basis for the construction of new, porphyrin-based, photobleaching herbicides to be exploited in efficient weed control.

\section{ACKNOWLEDGEMENTS}

This work was supported by the Korea Research Foundation Grant funded by the Korean Government (MOEHRD) (KRF-2006-531-F00004).

\section{요 약}

색소체 transit 서열이 결여된 Bradyrhizobium japonicum ALA-S 유전자를 과발현하는 형질전환 벼 의 광역학적 스트레스에 의해 유도되는 항산화반응 을 조사하였다. $350 \mu \mathrm{mol} \mathrm{m} \mathrm{m}^{-2}$ 의 높은 광 수준은 야 
생형 벼에 비교하였을 때 형질전환 계통인 $\mathrm{C} 4$ 와 $\mathrm{C} 5$ 의 quantum yield를 감소시켰다. 대조적으로, 높은 광 수준 하에서 형질전환 계통 $\mathrm{C} 4$ 와 $\mathrm{C} 5$ 의 nonphotochemical quenching (NPQ) 수준은 야생형 계통 과 낮은 광 수준 하의 형질전환 계통에 비해 높은 증 가를 보여주었다. 형질전환 계통에서 높은 NPQ 수준 은 xanthophyll인 zeaxanthin 수준의 증가와 밀접한 관 련이 있었다. $150 \mu \mathrm{mol} \mathrm{m}^{-2} \mathrm{~s}^{-1}$ 의 낮은 광 수준과 비교 하였을 때 높은 광 수준에서 violaxanthin 수준이 야 생형 벼에서 증가하였으나, 형질전환 $\mathrm{C} 4$ 와 $\mathrm{C} 5$ 계통 에서는 현저하게 감소하였다. 형질전환 벼에서 nonphotochemical energy dissipation과 광보호기작을 가진 xanthophyll 색소가 광역학적 피해를 조절하는데 결정적인 역할을 하는 것으로 생각되나, 이러한 기작 이 광역학 스트레스를 극복하지는 못하였고 결과적으 로 photobleaching 증상에 이르게 하였다.

\section{REFERENCES}

Back, K., and S. Jung. 2010. The lack of plastidal transit sequence cannot override the targeting capacity of Bradyrhizobium japonicum $\delta$-aminolevulinic acid synthase in transgenic rice. Biol. Plant. 54:279284.

Beale, S. I. 1978. $\delta$-Aminolevulinic acid in plants : its biosynthesis, regulation, and role in plastid development. Annu. Rev. Plant Physiol. 29:95-120.

Bilger, W., and O. Björkman. 1990. Role of the xanthophyll cycle in photoprotection elucidated by measurements of light-induced absorbance changes, fluorescence and photosynthesis in leaves of Hederacanariensis. Photosynth. Res. 25:173-185.

Demmig-Adams, B., W. W. Adams III, D. H. Barker, B. A. Logan, D. R. Bowling and A. S. Verhoeven. 1996. Using chlorophyll fluorescence to assess the fraction of absorbed light allocated to thermal dissipation of excess excitation. Physiol. Plant. 98: 253-264.

Foyer, C. H., M. Lelandais and K. J. Kunert. 1994. Photooxidative stress in plants. Physiol. Plant.
92:696-717.

Genty, B., J. M. Briantais and N. Baker. 1989. The relationship between the quantum yield of photosynthetic electron transport and quenching of chlorophyll fluorescence. Biochim. Biophys. Acta 990:87-92.

Gilmore, A. M., and H. Y. Yamamoto. 1991. Zeaxanthin formation and energy-dependent fluorescence quenching in pea chloroplasts under artificiallymediated linear and cyclic electron transport. Plant Physiol. 96:635-643.

Gilmore, A. M., and H. Y. Yamamoto. 1993. Linear models relating xanthophylls and lumen acidity to non-photochemical fluorescence quenching. Evidence that antheraxanthin explains zeaxanthin-independent quenching. Photosynth. Res. 35:67-78.

Hopf, F. R., and D. G. Whitten. 1978. Chemical transformations involving photoexcited porphyrins and metalloporphyrins. pp. 191-195. In D. Dolphin, ed. The Porphyrins. Vol. 2. Academic Press, New York.

Hotta, Y., T. Tanaka, H. Takaoka, Y. Takeuchi and M. Konnai. 1997. Promotive effects of 5-aminolevulinic acid on the yield of several crops. Plant Growth Regul. 22:109-114.

Jung, S. 2009. Differential photodynamic-induced oxidative stress imposed by aminolevulinic acid and oxyfluorfen. Kor. J. Weed Sci. 29:336-342.

Jung, S., and K. L. Steffen. 1997. Influence of photosynthetic photon flux densities before and during long-term chilling on xanthophyll cycle and chlorophyll fluorescence quenching in leaves of tomato (Lycopersicon hirsutum). Physiol. Plant. 100:958-966.

Krause, G. H. 1988. Photoinhibition of photosynthesis. An evaluation of damaging and protective mechanisms. Physiol. Plant. 74:566-574.

Lichtenthaler, H. K. 1987. Chlorophylls and carotenoids : pigments of photosynthetic biomembranes. Methods Enzymol. 148:350-382.

Mittler, R., S. Vanderauwera, M. Gollery and F. Van 
Breusegem. 2004. Reactive oxygen gene network of plants. Trends Plant Sci. 9:490-498.

Niyogi, K. K., O. Björkman and A. R. Grossman. 1997. The roles of specific xanthophylls in photoprotection. Proc. Natl. Acad. Sci. USA 94:14162-14167.

Rebeiz, C. A., A. Montazer-Zouhoor, H. J. Hopen and S. M. Wu. 1984. Photodynamic herbicides : Concept and phenomenology. Enzyme Microb. Tech. 6: 390-401.

Ruban, A. V., A. J. Young and P. Horton. 1993. Induction of nonphotochemical energy dissipation and absorbance changes in leaves. Evidence for changes in the state of the light-harvesting system of photosystem II in vivo. Plant Physiol. 102: 741-750.

Sasaki, K., T. Tanaka and S. Nagai. 1998. Use of photosynthetic bacteria for the production of SCP and chemicals from organic wastes. pp. 247-291. In A. M. Martin, ed. Bioconversion of Waste Materials to Industrial Products. Second Edition. Blackie Academic and Professional.

Schreiber, U., W. Bilger and C. Neubauer. 1994. Chlorophyll fluorescence as a non-intrusive indicator for rapid assessment of in vivo photosynthesis. pp. 49-70. In E. D. Schulze and M. M. Caldwell, eds. Ecology of Photosynthesis. Springer-Verlag, Berlin. Sharma, J., M. Panico, J. Barber and H. R. Morris. 1997. Purification and determination of intact molecular mass by electrospray ionization mass spectrometry of the photosystem II reaction center subunits. J. Biol. Chem. 272:33153-33157.

Trebst, A. 2003. Function of beta-carotene and tocopherol in photosystem II. Z. Naturforsch. C58:609620.

Tripathy, B. C., and N. Chakraborty. 1991. 5Aminolevulinic acid induced photodynamic damage of the photosynthetic electron transport chain of cucumber (Cucumis sativus L.) cotyledons. Plant Physiol. 96:761-767.

von Wettstein, D., S. Gough and C. G. Kannangara. 1995. Chlorophyll biosynthesis. Plant Cell 7:10391057.

Weis, E., and J. A. Berry. 1987. Quantum efficiency of photosystem II in relation to energy-dependent quenching of chlorophyll fluorescence. Biochim. Biophys. Acta 894:198-208. 